- FINANSE I PRAWO FINANSOWE.

- Journal of Finance and Financial Law

Grudzień/December 2020 • vol. 4(28): 45-63

http://dx.doi.org/10.18778/2391-6478.4.28.03

\title{
OCHRONA KONSUMENTÓW NA RYNKU KAPITAŁOWYM W POLSCE
}

\author{
dr Maria Czech \\ Katedra Bankowości i Rynków Finansowych \\ Uniwersytet Ekonomiczny w Katowicach
}

ORCID: https://orcid.org/0000-0003-3572-6891

\begin{abstract}
Streszczenie
Prawidłowe funkcjonowanie rynku kapitałowego determinowane jest utrzymywaniem wymaganego poziomu bezpieczeństwa jego uczestników. Z uwagi na liczne zagrożenia, rynek kapitałowy jest szczególnie wymagający dla konsumentów, którzy na własne ryzyko dokonują obrotu instrumentami finansowymi (inwestorzy indywidualni). Do głównych zagrożeń zalicza się przede wszystkim deficyty informacji, zmienność uwarunkowań rynkowych, a także nieuczciwe praktyki rynkowe oraz upadłość biur maklerskich, w których utrzymują instrumenty finansowe lub środki pieniężne.

Celem opracowania jest wskazanie zakresu ochrony konsumentów usług finansowych na rynku kapitałowym. W opracowaniu stawia się hipotezę, że ochrona konsumentów na rynku kapitałowym jest niewystarczająca i wymaga wprowadzenia kompleksowych rozwiązań w zakresie spójnego systemu ochrony.

W artykule wykorzystuje się dwie metody badawcze. Pierwszą metodą, jest analiza dokumentów i aktów prawnych. Jej celem jest przedstawienie zakresu udzielenia ochrony konsumentom usług maklerskich. Drugą metodą badawczą jest empiryczna analiza dynamiki, której celem jest wskazanie tendencji oraz dynamiki zmian aktywności konsumentów usług maklerskich.
\end{abstract}

Słowa kluczowe: ochrona konsumentów, inwestor indywidualny, System Rekompensat, usługi maklerskie, rynek kapitałowy.

JEL Class: D18 G23, G24, G29. 


\section{WSTĘP}

Zarówno polskie, jak i unijne normy prawne, ujawniają szeroko rozumiane pojęcie „konsument”. Znajduje się on w obszarze zainteresowania różnych dyscyplin naukowych [Janik 2007: 13] i jest różnie ujmowany w poszczególnych aktach normatywnych [Szczepańska 2011: 161-178; Rutkowska-Tomaszewska 2020b: 481-498]. Prawodawstwo unijne definiuje konsumenta jako osobę fizyczną, działającą w celach niezwiązanych z wykonywaniem wolnego zawodu, działalnością gospodarczą, rzemieślniczą i handlową [Dyrektywa 2002/65/WE; Dyrektywa 2005/29/WE; Dyrektywa 2011/83/UE; Dyrektywa 2013/11/UE]. Na gruncie prawa polskiego konsumentem jest osoba fizyczna, dokonująca czynności prawnej z przedsiębiorcą, pod warunkiem, że czynność ta nie jest bezpośrednio związana $\mathrm{z}$ działalnością gospodarczą lub zawodową konsumenta [Ustawa $\mathrm{z}$ dnia 23 kwietnia 1964 r. ....].

Na rynku kapitałowym dokonywanie czynności prawnej konsumenta z przedsiębiorcą dotyczy świadczenia usług finansowych. Usługi te związane są przede wszystkim z pozyskiwaniem oraz z lokowaniem środków pieniężnych na rynku finansowym, a także z zapewnieniem odpowiedniej płynności na tym rynku [Iwanicz-Drozdowska i in. 2009: 10]. Sa to usługi o charakterze niematerialnym [Gnela 2007: 139]. W efekcie powstają trudności związane z brakiem możliwości sprawdzenia i zweryfikowania ich jakości przed dokonaniem zakupu [Sójka 2016: 29-30; 95]. Jakość usług finansowych nie jest stała, ale różni się np. w zależności od osób je świadczących lub od czasu ich wykonywania. Ryzyko jakości usługi finansowej zależy przede wszystkim od usługodawcy, bowiem nie istnieje możliwość rozdzielenia usługi od usługodawcy [Janik 2007: 25]. W wyniku niekompetencji, zaniedbania czy nieuczciwości usługodawcy, jakość usługi może ulegać istotnemu obniżeniu [Llewellyn 1999: 42-44].

Z usług finansowych korzystają zarówno klienci detaliczni (którzy w myśl prawa spełniają definicję konsumenta), jak i klienci profesjonalni ${ }^{1}$. Z uwagi na fakt, że niniejsze opracowanie podejmuje problem ochrony konsumenta na rynku kapitałowym, konsument usług finansowych jest tożsamy $\mathrm{z}$ inwestorem indywidualnym. Inwestor ten zawiera transakcje zakupu-sprzedaży instrumentów finansowych osobiście, na własne ryzyko i własny rachunek, z pominięciem usług inwestorów profesjonalnych [Cichorska 2015: 26]. W rezultacie jest on bardziej narażony na ryzyko pokusy nadużycia [DKN przy Rzeczniku Finansowym, 2019: 275] i ryzyko związane $\mathrm{z}$ asymetrią informacji występującą pomiędzy nimi a dostawcami usług finansowych [Frączek i Mitręga-Niestrój 2015: 5-15; Sójka 2016: 29].

${ }^{1}$ Klient profesjonalny (np. bank, firma inwestycyjna, zakład ubezpieczeń, fundusz inwestycyjny czy fundusz emerytalny podejmuje decyzje inwestycyjne na podstawie wiedzy oraz doświadczenia i potrafi ocenić ryzyko związane z podejmowanymi decyzjami [Ustawa z dnia 29 maja 2005 r. ..., art. 3.39b), art. 3.39c)]. 
Celem głównym opracowania jest wskazanie zakresu ochrony konsumentów usług finansowych (inwestorów indywidualnych) na rynku kapitałowym. W opracowaniu stawia się hipotezę, że ochrona konsumenta na rynku kapitałowym jest niewystarczająca i wymaga wprowadzenia kompleksowych rozwiązań w zakresie spójnego systemu ochrony.

\section{PROFIL KONSUMENTA NA RYNKU KAPITAŁOWYM}

Od 17 lat Stowarzyszenie Inwestorów Indywidualnych (SII) prowadzi Ogólnopolskie Badania Inwestorów (OBI). W oparciu o jego wyniki zostaje określony profil polskiego inwestora indywidualnego. Ostatnie Ogólnopolskie Badania Inwestorów przeprowadzono w 2019 r. Na jego podstawie stwierdza się, że grupa inwestorów indywidualnych jest zróżnicowana w swojej istocie. Wśród nich dominują mężczyźni, którzy stanowią ponad 90,80\% wszystkich inwestorów. Ich średni wiek określony jest na 42 lata, ale najbardziej aktywnymi inwestorami są ci, którzy mieszczą się w przedziale wiekowym 26-45 lat (59\%). Z badania wynika, że na rynku finansowym najczęściej inwestują inwestorzy wysoko wykwalifikowani. Ponad $26 \%$ inwestorów ukończyło wyższe studia o profilu ekonomicznym, natomiast kolejne $48 \%$ ukończyło wyższe studia o profilu innym niż ekonomiczny [SII 2019].

OBI wykazało, że średnia wartość portfela inwestora indywidualnego w $2019 \mathrm{r}$. była określana na 50 tys. zł. Najwięcej inwestorów (34,2\%) posiadało portfel o wartości do 30 tyś. zł., ale znaczna część inwestorów (21,6\%) utrzymywało portfel o wartości od 100-500 tys. zł. Najpopularniejszym składnikiem portfela w 2019 r. były akcje GPW (81,9\%) oraz akcje NewConnect $(27,3 \%)$, natomiast instrumenty pochodne stanowiły zaledwie $14,1 \%$ portfela [SII 2019]. Przedstawione wyniki znajdują potwierdzenie w obrotach giełdowych, bowiem w $2019 \mathrm{r}$. udział inwestorów indywidualnych był zróżnicowany - w obrotach na rynku głównym jest najmniejszy (zob. wykres 1), natomiast w obrotach na rynku instrumentów pochodnych i NewConnect był największy (zob. wykres 3).

Udział inwestorów indywidualnych na głównym rynku akcji GPW znajduje się w trendzie malejącym. Oznacza to powolne, ale systematyczne wycofywanie się tej grupy inwestorów z rynku. Największy udział inwestorów indywidualnych (38\%) odnotowano w czerwcu 2004 r., co wynikało z niskiego zaangażowania inwestorów zagranicznych (29\%) i instytucjonalnych (33\%). Powtórnie wysoki udział inwestorów indywidualnych w tym rynku odnotowano w latach 20062007. W tym okresie wartość transakcji zawartych przez inwestorów indywidualnych była najwyższa w całym badanym okresie (zob. wykres 2). 


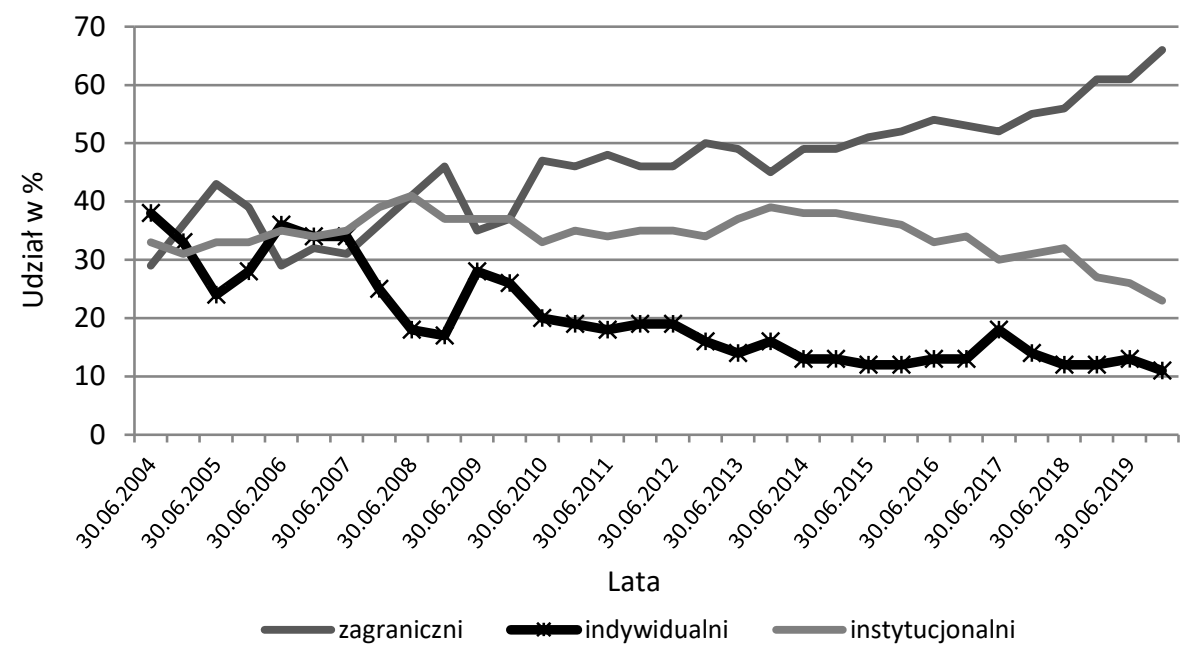

Wykres 1. Udział inwestorów indywidualnych w rynku akcji

Źródło: opracowanie własne na podstawie GPW.

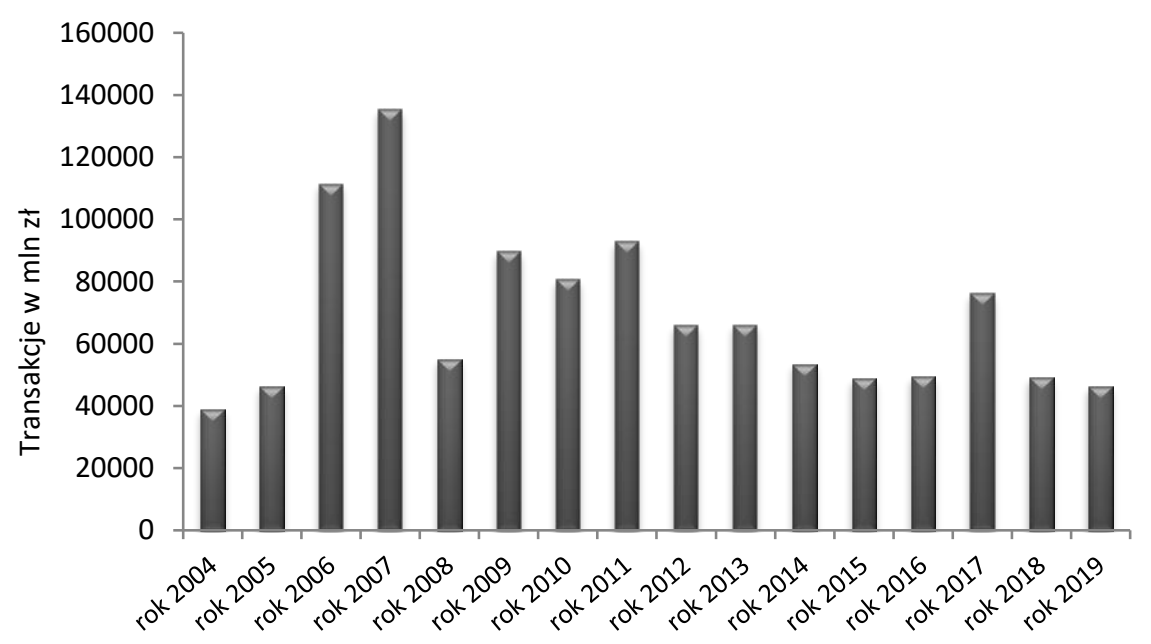

Lata

Wykres 2. Transakcje inwestorów indywidualnych na rynku głównym GPW

Żródło: opracowanie własne na podstawie GPW 2020. 

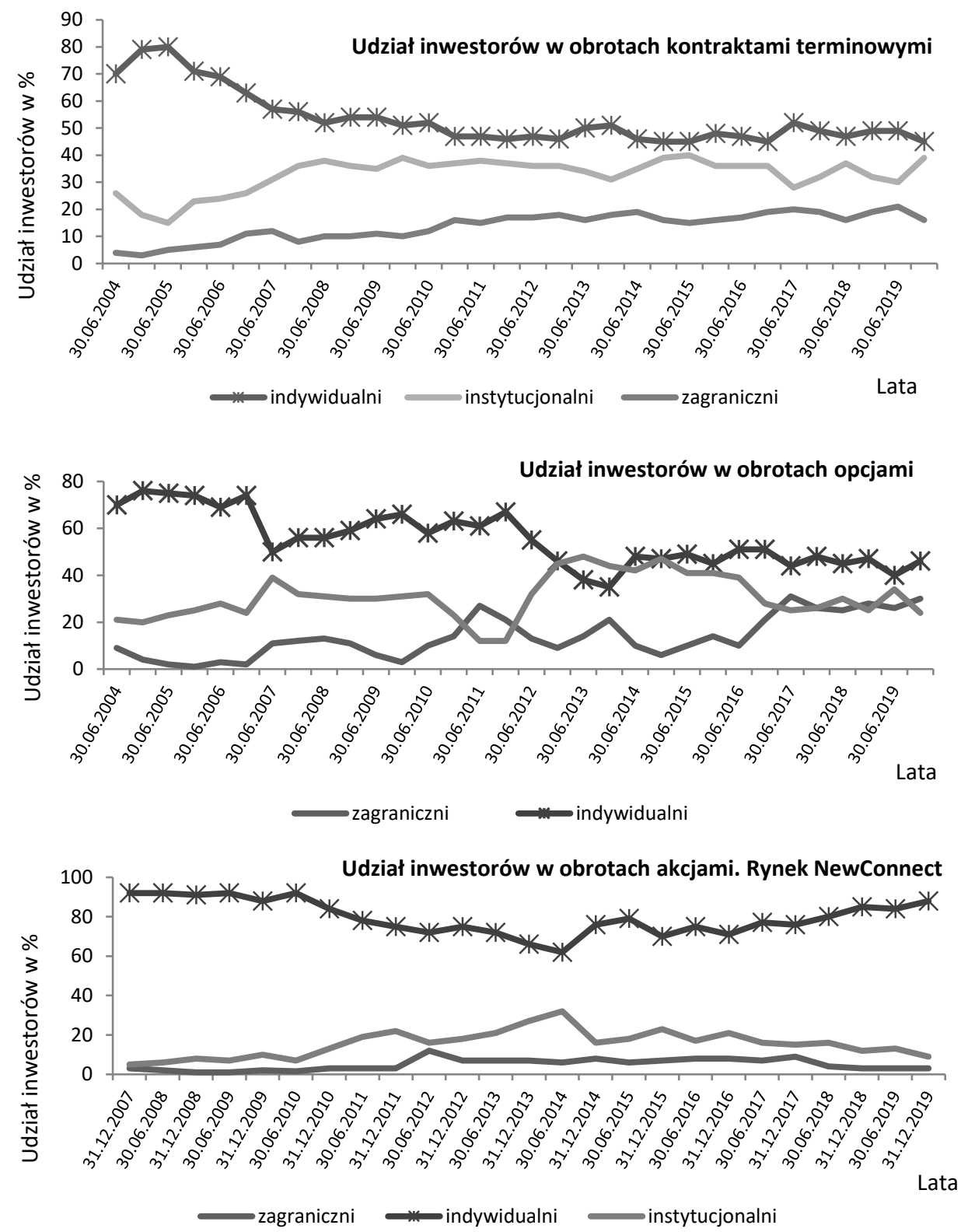

Wykres 3. Udział inwestorów na rynku NewConnect, oraz w obrotach kontraktami terminowymi i opcjami

Źródło: opracowanie własne na podstawie GPW 2020. 
Od 2007 r. wartość transakcji zawieranych przez inwestorów indywidualnych na rynku głównym spadała z roku na rok średnio o $8,60 \%$. Trend malejący wynika z powolnej, ale systematycznej zamiany preferencji dotyczącej przedmiotu inwestycji. Inwestorzy indywidualni coraz chętniej lokowali środki pieniężne w inne instrumenty (akcje NewConnect, instrumenty pochodne). Pokazuje to trend wykazany w kolejnych edycjach Ogólnopolskiego Badania Inwestorów. Potwierdza to również udział inwestorów indywidualnych w obrotach instrumentami pochodnymi, które notowane są na GPW oraz udział tych inwestorów na rynku NewConnect (zob. wykres 3).

W latach 2004-2019 udział inwestorów indywidualnych w obrotach kontraktami terminowymi i opcjami był najwyższy w całym okresie badawczym. Ich największy udział w obrocie instrumentami pochodnymi odnotowano w latach 20042006. Natomiast w kolejnych latach udział ten pozostawał na względnie stabilnym poziomie, mimo systematycznie rosnącego zaangażowania inwestorów instytucjonalnych i zagranicznych. Podobną tendencję zaobserwowano na rynku NewConnect, gdzie od momentu jego powstania (2007 r.) udział inwestorów indywidualnych w obrotach był najwyższy w całym okresie badawczym. Zarówno inwestorzy instytucjonalni, jak również inwestorzy zagraniczni, wykazywali bardzo małą aktywność w obrotach w ciągu całego okresu funkcjonowania tego rynku. Udział w obrotach tych dwóch grup inwestorów w 2019 roku wyniósł zaledwie 3\% (inwestorzy zagraniczni) i 9\% inwestorzy instytucjonalni. Przedstawione wyniki zostały potwierdzone w wynikach OBI, które wykazały rosnące zaangażowanie inwestorów indywidualnych zarówno na rynku NewConnect, jak również rosnącą aktywność w obrotach instrumentami pochodnymi.

Z OBI wynika również, że coraz więcej inwestorów indywidualnych lokuje środki pieniężne na rynku kapitałowym średnio lub długoterminowo. W 2019 r. ponad 52\% inwestorów utrzymywało akcje w portfelu powyżej 1 roku, 33\% inwestorów wyprzedawało posiadane akcje przed upływem roku, a $10 \%$ sprzedawało przed upływem tygodnia. Porównując powyższe wyniki do wyników z lat ubiegłych, stwierdza się, iż inwestorzy indywidualni mimo spadającego udziału w obrotach na głównym rynku akcji na GPW, coraz bardziej dywersyfikują portfel posiadanych akcji, bowiem 8 i więcej spółek w portfelu w 2019 utrzymywało $28,10 \%$ inwestorów (dla porównania w 2011 roku zaledwie 11,4\%), natomiast 4 7 spółek w portfelu utrzymywało 41,1\% inwestorów (w 2011 roku 38,8\%). Jednocześnie znacznie zmniejszył się odsetek inwestorów utrzymujących 2-3 spółki w portfelu (26,4\% w 2019 r., w porównaniu do 2011 r.: 41,6\%) (zob. wykres 4). 


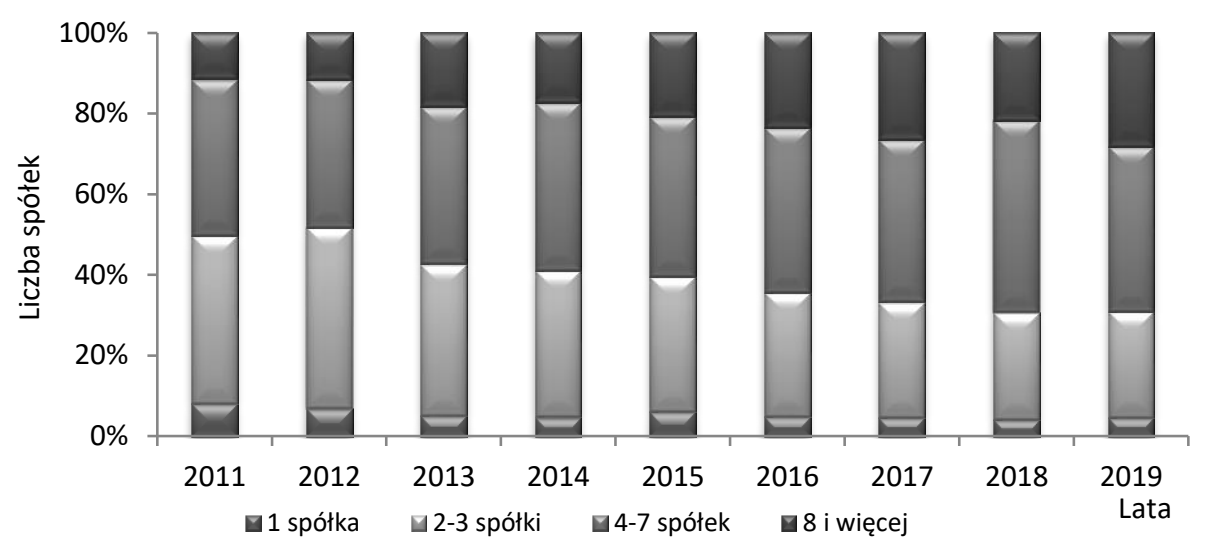

Wykres 4. Liczba spółek w portfelu inwestorów indywidualnych w latach 2011-2019

Źródło: SII 2019.

Wyniki OBI wskazują, że zdecydowana większość inwestorów indywidualnych jest niezależna, bowiem inwestuje samodzielnie. W 2019 r. prawie połowa badanych inwestorów dokonywała inwestycji w oparciu o połączenie analizy fundamentalnej i technicznej (45,7\%), 25,4\% wybierała tylko analizę fundamentalną, a $15,9 \%$ tylko analizę techniczną. Wśród inwestorów występował duży odsetek podmiotów kierujących się informacjami pochodzącymi przede wszystkim z raportów bieżących i okresowych spółek, ale równocześnie dużo inwestorów korzystało z serwisów informacyjnych ${ }^{2}$. Mimo że w 2019 r. aż 95\% inwestorów indywidualnych dokonywało obrotu instrumentami finansowymi za pomocą własnego rachunku inwestycyjnego, to czas, jaki poświęcali na śledzenie inwestycji i szukanie nowych okazji inwestycyjnych, można określić jako niewielki. 31\% inwestorów przeznaczało na inwestowanie godzinę dziennie, $25 \%$ kilka godzin w tygodniu, natomiast $16 \%$ kilka godzin w miesiącu. Tylko $20 \%$ inwestorów zajmowało się swoimi inwestycjami kilka godzin dziennie. Wynika to z faktu, że inwestycje na rynku kapitałowym nie są jedynym źródłem dochodów inwestorów indywidualnych. Świadczy o tym fakt, że w 2019 r. niespełna $61 \%$ inwestorów pracowało na umowę o pracę lub umowę zlecenie. Świadczy o tym również cel

${ }^{2}$ Inwestorzy najczęściej korzystali z serwisów internetowych: bankier.pl $(69,1 \%)$, stooq.pl (47,6\%), money.pl (43,2\%), parkiet.com (33,5\%), stockwatch.pl (29,4\%), strefainwestorów.pl $(25,8 \%)$; z gazet: Parkiet (33,3\%), Puls Biznesu (32\%), Forbes (13\%); z kanałów telewizyjnych: TVN24BiŚ (27\%), TVN24 (12,9\%), ParkietTV (12,1\%), Bloomberg (10,4\%), natomiast 36\% nie korzysta z gazet, $46 \%$ nie korzysta z telewizji i 76,9\% inwestorów nie korzysta z radia jako źródła informacji. 
zawierania transakcji na rynku kapitałowym, którym najczęściej była dywersyfikacja źródeł dochodu.

Na rynku kapitałowym występują również konsumenci usług finansowych, którzy znacząco odbiegają od przedstawionego profilu inwestora indywidualnego. Są to konsumenci, którzy szukając możliwości ulokowania posiadanych nadwyżek pieniężnych, ulegają presji agresywnych technik sprzedaży usług finansowych na rynku kapitałowym [Rzecznik Finansowy 2018: 3]. Wśród nich znajdują się zwykle osoby starsze oraz osoby nieposiadające dostatecznej wiedzy na temat funkcjonowania rynku kapitałowego, instrumentów finansowych ani też ryzyka, jakie ponoszą [Rzecznik Finansowy 2017: 1]. Dokonując zakupu często skompilowanych usług finansowych, konsumenci ci zwykle nie mają zdolności oceny poprawności zapisów zawartych umów i kierują się wyłącznie zaufaniem do instytucji oferującej określone usługi finansowe [Rutkowska-Tomaszewska 2020a: 72-89]. Takim inwestorom należy się szczególna ochrona, bowiem to oni są najbardziej narażeni na nadużycia ze strony instytucji finansowych, wykorzystujących asymetrię informacji na swoją korzyść. Tymczasem wykrywalność przestępstw wynikających z działalności instytucji finansowych na rynku finansowym jest bardzo niska (zob. wykres 5).

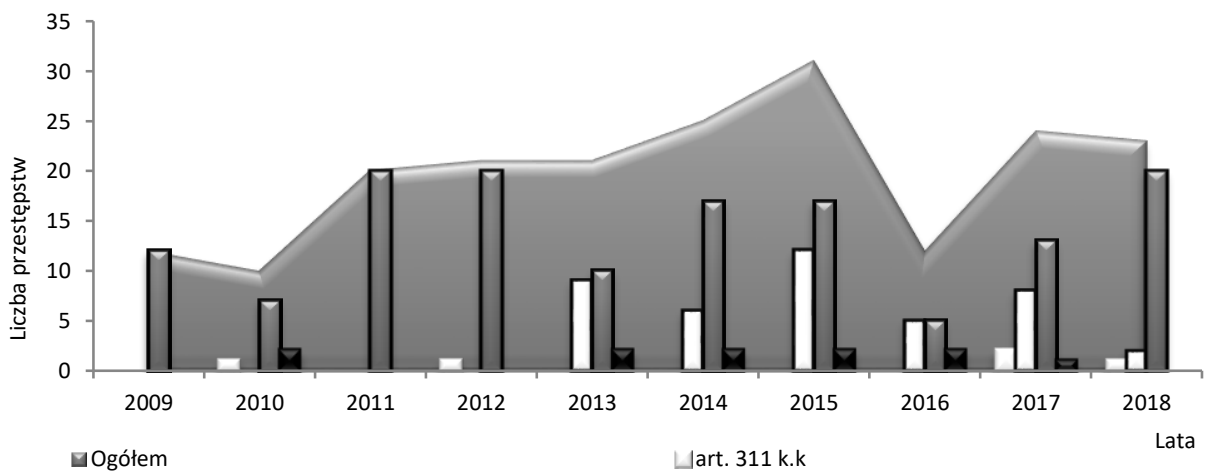

口Art. 287-296 ustawy o funduszach inwestycyjnych Dart. 178-183 ustawy o obr. instr. finan.

Dart. 38-41, 43, 43a ustawy o oblig.

Wykres 5. Liczba przestępstw z zakresu działalności instytucji rynku kapitałowego wykrytych przez Policję w latach 2009-2018

Źródło: opracowanie własne na podstawie KDPW 2020.

W latach 2009-2018 łączna liczba przestępstw naruszających bezpieczeństwo inwestorów indywidualnych, wyniosła 199 [DKN przy Rzeczniku Finansowym 2019: 41-42]. Wśród nich aż 183 to przestępstwa z tytułu odpowiedzialności 
karnej za: oferowanie usług finansowych bez zezwolenia, udzielania informacji3 lub dokonywanie manipulacji oraz nakłanianie do obrotu instrumentami finansowymi [Ustawa z dnia 29 maja 2005 r. ..., art.178-183; Ustawa z dnia 27 maja 2004 r. ..., art. 287-296]. Pozostałe wykryte przestępstwa dotyczyły niespełnienia ustawowych wymagań w zakresie emisji obligacji (z art. 38-41, 43, 43a ustawy o obligacjach) oraz fałszowania informacji (z art. 311 k.k) [DKN przy Rzeczniku Finansowym 2019: 41-42].

Konsumenci usług finansowych oferowanych na rynku kapitałowym mają prawo oczekiwać odpowiedniego poziomu bezpieczeństwa, bowiem ponoszą ryzyko utraty aktywów w wyniku niewypłacalności instytucji świadczących usługi finansowe $\mathrm{w}$ zakresie obrotu instrumentami finansowymi. Jednym $\mathrm{z}$ instrumentów wpływających na zwiększenie bezpieczeństwa inwestorów indywidualnych jest System Rekompensat.

\section{SYSTEM REKOMPENSAT JAKO ELEMENT SYSTEMU OCHRONY KONSUMENTÓW}

Przy zawieraniu transakcji zakupu-sprzedaży instrumentów finansowych na rynku kapitałowym pośredniczą wyspecjalizowane instytucje finansowe [Sójka 2016: 165], którym konsumenci powierzają aktywa, ponosząc ryzyko ich utraty w przypadku upadłości. Mechanizmem zabezpieczającym konsumentów przed ryzykiem strat z tytułu upadłości lub niewypłacalności instytucji pośredniczących jest System Rekompensat. Jest to system gromadzenia środków, które przeznaczone są na dodatkowe zabezpieczenie aktywów oraz częściowe zrekompensowanie wartości środków pieniężnych i utraconych instrumentów finansowych w sytuacji niewypłacalności lub upadłości firm inwestycyjnych [KDPW 2020]. Wypłaty rekompensat dokonuje się w przypadku:

- gdy przedsiębiorstwo inwestycyjne nie jest w stanie wypełnić swoich zobowiązań wynikających z roszczeń inwestorów i nie ma możliwości ich wypełnienia w najbliższym czasie,

- wydania przez organ sądowy orzeczenia, którego skutkiem jest zawieszenie możliwości dochodzenia przez inwestora swoich roszczeń od firmy inwestycyjnej, z powodów ściśle związanych z sytuacją finansową przedsiębiorstwa inwestycyjnego [Dyrektywa 97/9/We].

Podmiotami objętymi ochroną Systemu Rekompensat są konsumenci, na rzecz których uczestnicy Systemu Rekompensat świadczą usługi maklerskie [KDPW 2020: 5]. Z uwagi na zróżnicowaną koniunkturę na rynku kapitałowym liczba inwestorów podlegających pod System Rekompensat jest zmienna w czasie (zob. wykres 6).

${ }^{3}$ Dotyczy nieuprawnionego ujawnienia lub wykorzystywania informacji poufnej lub tajemnicy zawodowej albo też udzielania nieprawdziwych lub zatajanie prawdziwych informacji. 


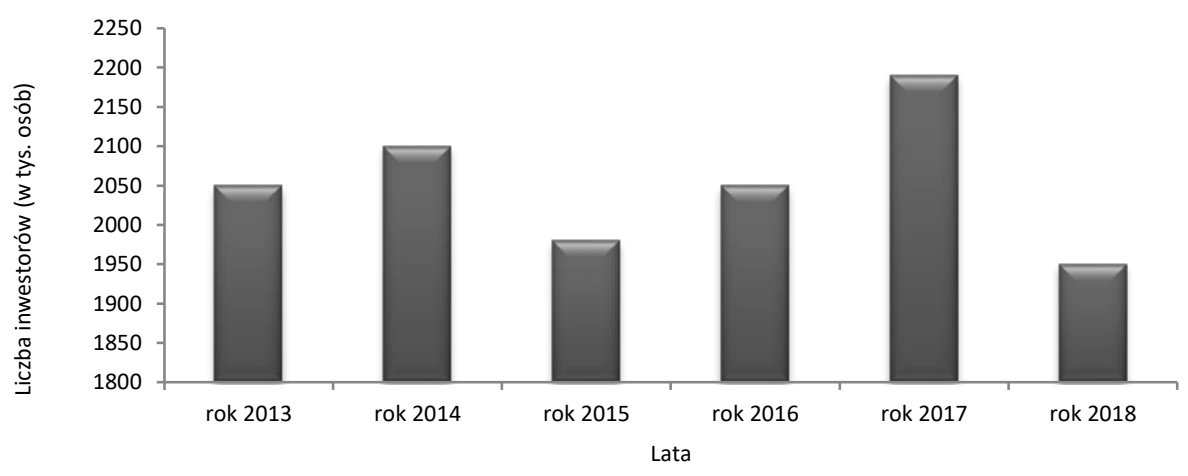

Wykres 6. Liczba inwestorów objętych ochroną Systemu Rekompensat (w tys. osób) w latach 2013-2018

Źródło: opracowanie własne na podstawie KDPW 2020.

Fluktuacje liczby konsumentów usług maklerskich wynikają głównie z tendencji panujących na rynkach [NBP 2014: 198; NBP 2015: 196; NBP 2016: 205; NBP 2017: 215; NBP 2018: 208; NBP 2019: 222]. Wahania popytu na usługi finansowe (które bezpośrednio przekładają się na liczbę konsumentów) argumentuje się także napływem środków netto do krajowych funduszy akcji małych i średnich spółek (w 2013 r.) oraz zmienną liczbą pierwotnych ofert publicznych na Rynku Głównym GPW ${ }^{5}$ [NBP 2014: 198; NBP 2015: 196; NBP 2016: 205; NBP 2017: 215; NBP 2018: 208; NBP 2019: 222].

Poważne spadki liczby inwestorów objętych Systemem Rekompensat odnotowano w 2015 r. oraz w 2018 r. Bezpośrednią przyczyną redukcji ich liczby w 2015 r. był ponad 19,7\% spadek kursów akcji spółek z WIG20 [NBP 2016: 205]. W konsekwencji, w 2016 r. oprócz ograniczenia pierwotnych emisji akcji i mniejszego popytu na usługi finansowe, odnotowano również zmniejszenie liczby uczestników Systemu Rekompensat (zob. wykres 7).

${ }^{4} \mathrm{Z}$ uwagi na duże ograniczenia w dostępie do danych, liczba inwestorów objętych Systemem Rekompensat, liczba uczestników Systemu oraz stan środków zgromadzonych w Systemie analizowane są w okresie 2013-2018.

${ }^{5}$ Wzrost liczby IPO na GPW odnotowano w 2013 r., 2015 r., 2017 r., a spadek w 2016 r. i 2018 r. 


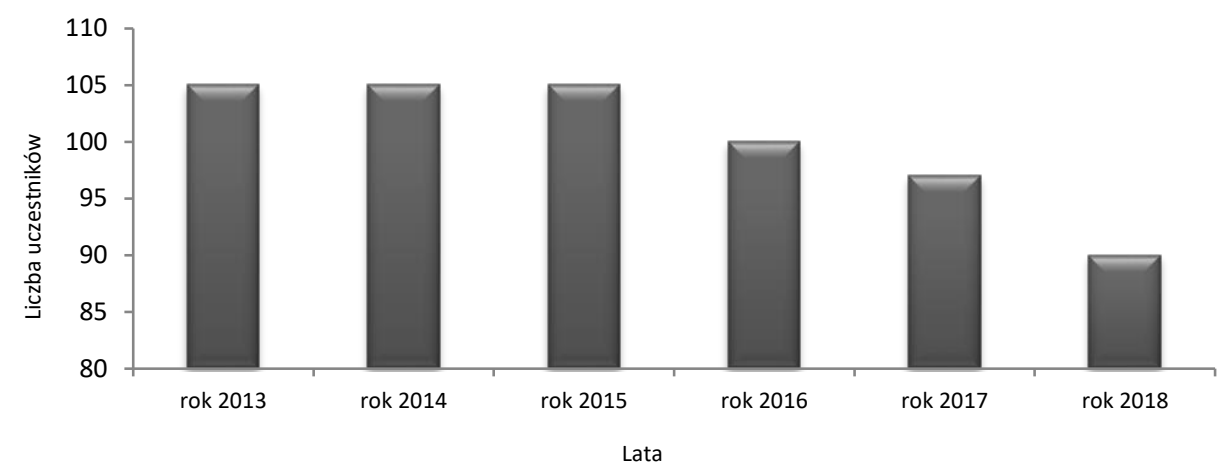

Wykres 7. Liczba uczestników Systemu Rekompensat w latach 2013-2018

Źródło: opracowanie własne na podstawie KDPW 2020.

Do uczestników Systemu Rekompensat zalicza się głównie domy maklerskie, ale również banki prowadzące działalność maklerską, banki powiernicze oraz towarzystwa funduszy inwestycyjnych [KDPW 2020: 5]. Wymienione podmioty zwykle działają w ramach grup kapitałowych, co w warunkach niekorzystnej koniunktury w 2015 r. umożliwiło im transfer usług finansowych z domów maklerskich do banków lub TFI, a w konsekwencji doprowadziło do zmniejszenia ich liczby w 2016 r. [NBP 2016: 205]. Oczekiwanym efektem dystrybucji usług finansowych $\mathrm{w}$ ramach jednego podmiotu była koncentracja bazy klientów przy jednoczesnej minimalizacji kosztów.

Ponowny znaczący spadek liczby uczestników Systemu Rekompensat odnotowano w 2018 r. Na skutek uchybień w prowadzeniu działalności maklerskiej, w tym nieprawidłowości w oferowaniu usług finansowych związanych ze sprzedażą obligacji GetBack SA ${ }^{6}$, KNF uchyliło zezwolenia na prowadzenie działalności maklerskiej dwóm domom maklerskim, a kolejni dwaj uczestnicy Systemu podjęli decyzję o zakończeniu działalności [NBP 2018: 223]. W wyniku afery związanej z działalnością spółki GetBack SA oraz nienależycie świadczonych usług finansowych, konsumenci stracili zaufanie do instytucji finansowych i wycofali się z rynku kapitałowego, co skutkowało zmniejszeniem liczby konsumentów objętych Systemem Rekompensat (zob. wykres 6).

${ }^{6}$ Przedsiębiorstwo windykacyjne GetBack SA w 2018 r. zaprzestało obsługi zobowiązań związanych z emisją obligacji, w wyniku czego duża liczba inwestorów utraciła zainwestowany kapitał. Ponadto, uchybienia dotyczyły także instytucji finansowych, które sprzedawały te obligacje bez należytej staranności - brak oceny wiedzy, doświadczenia i sytuacji konsumentów - wedle wymogów dyrektywy MiFID II (art. 25 ust. 3). Obligacje te były także oferowane przez instytucje nieposiadające zezwoleń na prowadzenie działalności maklerskiej [NBP 2019]. 
Uczestnicy Systemu Rekompensat są zobowiązani do corocznej wpłaty określonej sumy środków pieniężnych na rzecz Systemu Rekompensat. Srodki te podlegają akumulacji i stanowią kapitał do wypłaty rekompensat. W ciągu badanych 6 lat wartość środków pieniężnych wzrastała w średnim tempie $8,27 \%$ z roku na rok. Równocześnie wartość aktywów objętych ochroną pozostawała na względnie stałym poziomie (średnio $500 \mathrm{mld}$ zł). Wzrost środków pieniężnych wpłaconych przez uczestników Systemu o ponad 48\% (w latach 2013-2018) przy relatywnie stałej wartości aktywów świadczy o poprawie bezpieczeństwa konsumentów usług finansowych (zob. wykres 8).
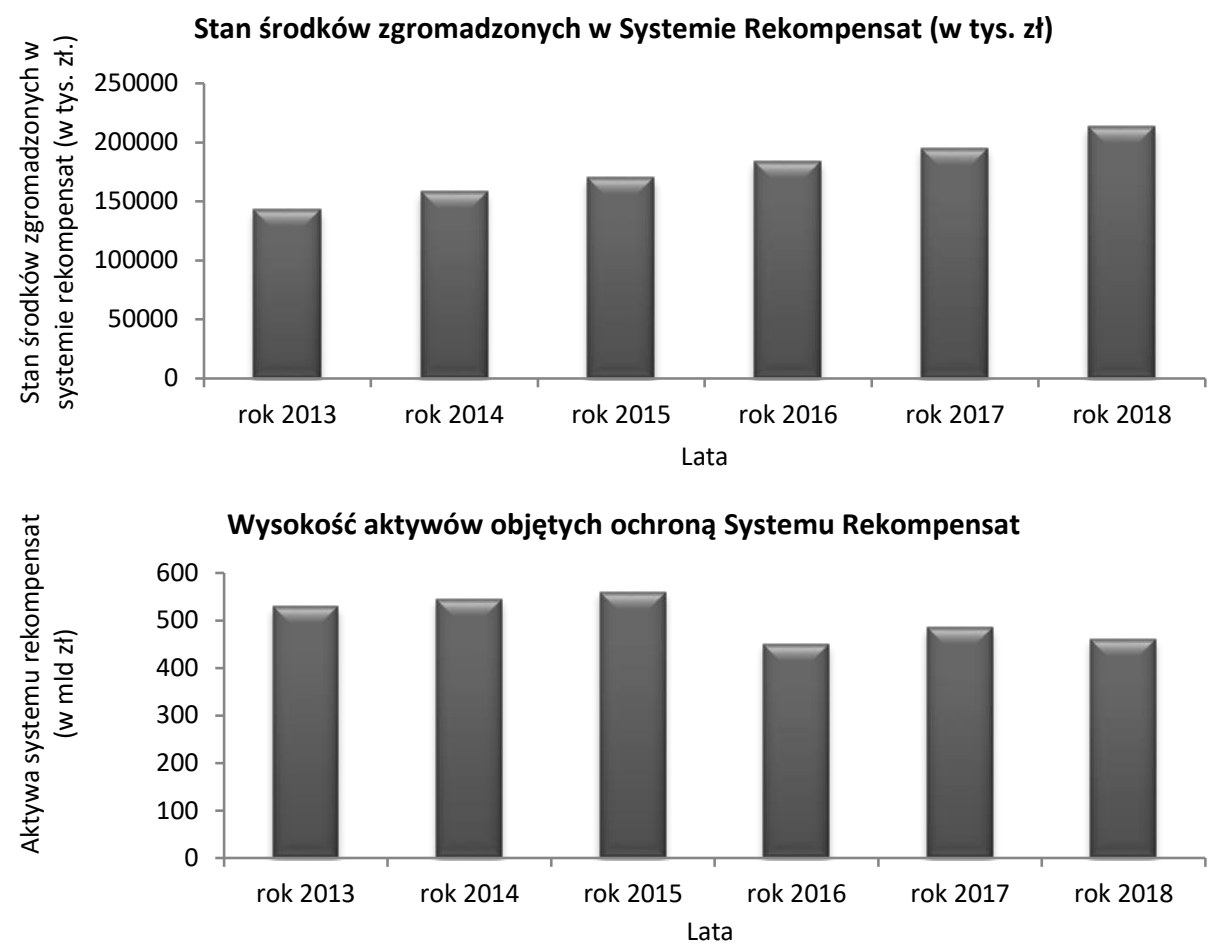

Wykres 8. Stan środków i wysokość aktywów objętych ochroną w Systemie Rekompensat w latach 2013-2018

Źródło: opracowanie własne na podstawie KDPW 2020.

Analizując uwarunkowania Systemu Rekompensat, należy zwrócić uwagę na ogromną dysproporcję pomiędzy środkami wpłaconymi do Systemu a wysokością aktywów, które podlegają ochronie. W 2018 roku rozpiętość pomiędzy zakumulowanymi środkami zgromadzonymi w Systemie a aktywami zabezpieczonymi 
tym Systemem wyniosła aż 215 830\%. Skala rozbieżności jest tak duża, że w przypadku całkowitego załamania rynku finansowego i upadłości uczestników Systemu, System stanie się niewydolny, a konsumenci nie otrzymają rekompensaty w wysokości utraconych środków. Scenariusz taki jest bardzo mało prawdopodobny, ale biorąc pod uwagę obecny kryzys zdrowotny i związane z nim obostrzenia, nie może być całkowicie wykluczony.

Wysokość rekompensat jest zróżnicowana, ze względu na wysokość aktywów konsumentów. System Rekompensat wypłaca $100 \%$ wartości środków do wysokości równowartości 3.000 euro, a powyżej tej kwoty tylko 90\%. Maksymalna wysokość roszczeń konsumenta wynosi równowartość $22000 €$, niezależnie od tego, w jakiej wysokości i na ilu rachunkach posiadał środki, a także niezależnie od tego z ilu wierzytelności przysługują mu należności w danym domu maklerskim. Ponadto, kwoty rekompensat wypłaconych inwestorom pomniejszone są o należności inwestorów względem domu maklerskiego, z tytułu świadczonych usług. Warto podkreślić, że rekompensaty są płatne według terminarza wypłat do 3 miesięcy od zatwierdzenia terminarza przez KDPW, a roszczenia przedawniają się po 5 latach.

Procedura wypłaty rekompensat zakłada, że w przypadku ogłoszenia niewypłacalności lub upadłości uczestnika Systemu powoływany jest Syndyk, którego zadaniem jest ustalenie stanu wierzytelności inwestorów i sporządzenie listy inwestorów uprawnionych do wypłaty rekompensat. Systemem Rekompensat administruje Krajowy Depozyt Papierów Wartościowych (KDPW), a całość Systemu nadzoruje Komisja Nadzoru Finansowego (KNF) (zob. rysunek 1).

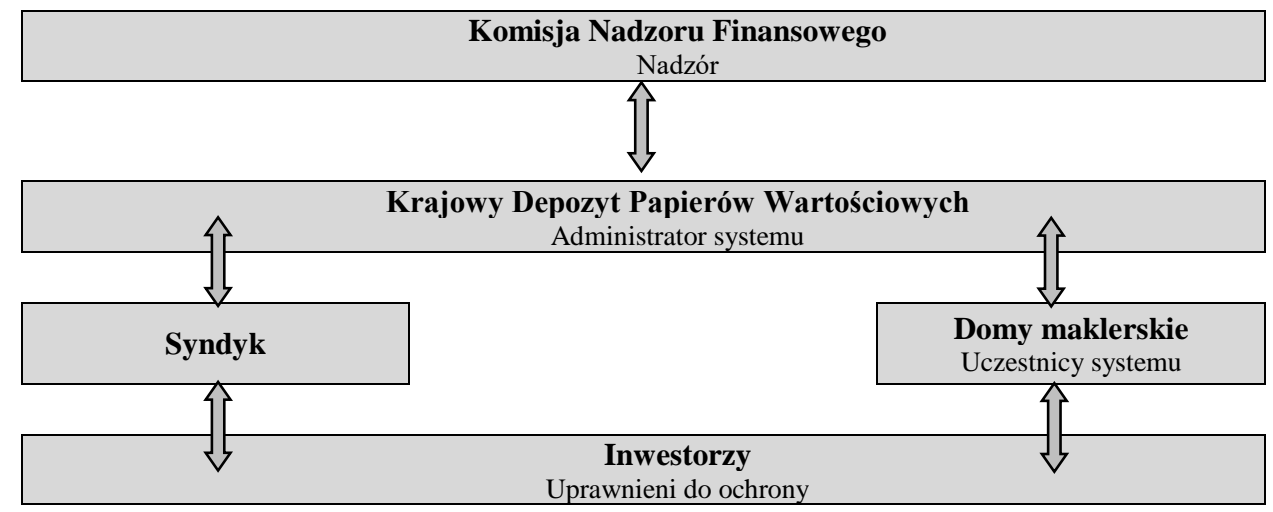

Rysunek 1. Struktura Systemu Rekompensat

Źródło: KDPW 2020. 
System Rekompensat nie został powołany w celu ochrony inwestorów przed ryzykiem poniesienia strat będących wynikiem niewłaściwie podjętych decyzji inwestycyjnych. Chroni jedynie przed niewypłacalnością podmiotów pośredniczących $\mathrm{w}$ obrocie instrumentami finansowymi. Prawo do rekompensaty będzie przysługiwało konsumentowi, który utracił posiadane aktywa w wyniku upadłości biura maklerskiego. Natomiast prawo do rekompensaty nie przysługuje konsumentowi, gdy na rachunku papierów wartościowych inwestora będą zapisane instrumenty finansowe i w momencie upadłości biura maklerskiego instrumenty te nadal będą zapisane na jego rachunku [KDPW 2020].

System Rekompensat jest zatem jednym z elementów, który chroni inwestorów indywidualnych, zapewniając prawo do odzyskania aktywów w przypadku upadłości instytucji pośredniczących w obrotach instrumentami finansowymi. Natomiast realną pomoc $\mathrm{w}$ rozwiązywaniu bieżących problemów konsumentów usług finansowych oferuje Stowarzyszenie Inwestorów Indywidualnych (SII).

\section{ROLA STOWARZYSZENIA INWESTORÓW INDYWIDUALNYCH W OCHRONIE PRAW KONSUMENTA}

Stowarzyszenie Inwestorów Indywidualnych jest najstarszą i jednocześnie największą w Polsce organizacją działającą na rzecz inwestorów - konsumentów usług świadczonych przez instytucje finansowe [SII 2015]. Powstało we Wrocławiu w 1999 r. Obecnie zrzesza ponad 15000 członków, których liczba stale wzrasta. SII wraz z organizacjami inwestorskimi Euroshareholders i Euro-investors oraz Światową Federacją Inwestorów WFIC tworzy międzynarodową społeczność inwestorów [SII 2020b]. Budowanie tej społeczności w Polsce odbywa się poprzez konferencje, działania edukacyjne, a także poprzez oferowanie profesjonalnych narzędzi, takich jak webinary analityczne, narzędzie umożliwiające personalizowanie sygnałów technicznych (ATskaner) oraz popularyzację literatury przedmiotu oferowanej przez partnerów SII, w tym również własnego czasopisma „Akcjonariusz”.

Jedną z głównych korzyści dla inwestorów indywidualnych, wynikających z działalności SII, jest zwiększanie poczucia ich bezpieczeństwa. Stowarzyszenie zapewnia wsparcie prawne i chroni prawa inwestorów [SII 2020a]. Członkowie SII mogą ubiegać się przede wszystkim o bezpłatną pomoc prawną udzielaną $\mathrm{w}$ formie konsultacji $\mathrm{w}$ zakresie interpretacji regulacji prawnych oraz zagadnień i problemów odnoszących się do rynku kapitałowego. Na zlecenie członków SII dokonuje oceny, czy w spółkach giełdowych doszło do naruszenia praw akcjonariuszy mniejszościowych. W sytuacji pojawienia się naruszeń interesów inwestorów indywidualnych, Stowarzyszenie udziela odpłatnej pomocy w zakresie 
przygotowania zawiadomień do prokuratury oraz przygotowania pism procesowych, a także reprezentuje inwestorów w postępowaniach karnych i sądowych.

SII podejmuje działania w kierunku zapewnienia powszechnego dostępu do informacji. Pełny dostęp do informacji inwestorów indywidualnych bezpośrednio wpływa na ich decyzje inwestycyjne i poprawia bezpieczeństwo inwestycji. Oprócz pełnego dostępu do informacji na poziom bezpieczeństwa inwestycji inwestorów wpływa również pomoc SII w analizie bieżących komunikatów spółek giełdowych. Ponadto, SII czuwa nad przestrzeganiem reguł uczciwego obrotu i tworzeniem standardów komunikacji spółek giełdowych z inwestorami indywidualnymi. W przypadku zainteresowania udziałem większej grupy członków SII w walnych zgromadzeniach akcjonariuszy (WZA), SII angażuje się w proces ich partycypacji. W sytuacji podejmowania przez WZA decyzji niekorzystnych z punktu widzenia interesów inwestorów mniejszościowych, SII wyraża chęć pomocy przy skarżeniu uchwał WZA. Wspiera także inwestorów indywidualnych w mediacjach oraz w negocjacjach zarówno ze spółkami giełdowymi, jak i z brokerami.

Dzięki współpracy Stowarzyszenia $\mathrm{z}$ renomowanymi kancelariami prawnymi, SII wyraża gotowość odpłatnej pomocy członkom Stowarzyszenia oraz podmiotom niebędących jego członkami w analizie umów inwestycyjnych, zarówno pod kątem prawnym, jak i z punktu widzenia bezpieczeństwa inwestorów. Umożliwia także sporządzenie analiz prawnych oraz pomoc przy dochodzeniu roszczeń inwestorów. W razie konieczności, SII udziela wsparcia w procesie reklamacyjnym do brokerów.

SII podejmuje również działania polegające na współpracy z organami administracji publicznej. Świadczy usługi w zakresie sporządzania wniosków o udzielenie indywidualnych interpretacji podatkowych.

Efektem działań Stowarzyszenia w zakresie poprawy bezpieczeństwa inwestorów jest przeprowadzenie wielu interwencji, głównie wobec akcjonariuszy większościowych, ale również w domach maklerskich oraz spółkach giełdowych [SII 2020a]. Działania te są podejmowane na zlecenie inwestorów, jak również z własnej inicjatywy Stowarzyszenia. Oprócz podejmowania działań interwencyjnych, SII udziela inwestorom indywidualnym ponad 2000 porad rocznie. Korzystając z usług Działu Ochrony Praw, inwestorzy otrzymują realną pomoc w rozwiązywaniu trudnych spraw, a tym samym wpływają na zwiększenie poziomu własnego bezpieczeństwa na rynku kapitałowym.

\section{PODSUMOWANIE}

Poprawa bezpieczeństwa inwestorów indywidualnych jest istotnym elementem prawidłowego funkcjonowania rynku kapitałowego w Polsce. Jednakże dotychczasowe rozwiązania w tym zakresie są niewystarczające. Dokonując obrotu 
instrumentami finansowymi na GPW za pomocą własnego rachunku inwestycyjnego, inwestorzy indywidualni zmuszeni są do korzystania z usług podmiotów pośredniczących. $Z$ tego tytułu inwestorzy indywidualni oraz domy maklerskie, zawierając umowę zakupu-sprzedaży instrumentów finansowych, dokonują czynności prawnej. Z uwagi na fakt, że działalność inwestorów indywidualnych nie jest bezpośrednio związana z ich działalnością gospodarczą ani z ich działalnością zawodową, dowiedziono, że spełniają oni definicję konsumenta.

W opracowaniu wykazano, że inwestorzy indywidualni odgrywają bardzo istotną rolę na rynku kapitałowym, mimo, że dysponują znacznie mniejszymi zasobami finansowymi i czasowymi względem inwestorów instytucjonalnych i zagranicznych. Konsumenci usług finansowych przede wszystkim dostarczają płynności na rynek kapitałowy, zwłaszcza w obszarze alternatywnego systemu obrotu oraz w obrocie instrumentami pochodnymi. Badania pokazały, że inwestorzy indywidualni dominują pod względem udziału w rynku NewConnect (średni udział $79,68 \%$ ), w rynku kontraktów terminowych (średni udział 43,41\%) oraz w rynku opcji (średni udział 55,41\%). Z przeprowadzonych badań równocześnie wynika, że mimo podtrzymywania obrotów na tych rynkach, inwestorzy indywidualni nie czują się wystarczająco chronieni. Dowodem tego jest masowe wycofywanie się konsumentów z rynku kapitałowego w okresie niekorzystnej koniunktury (np. w latach 2008 i 2015) oraz w okresach, w których dochodzi do nadużyć ich interesów przez instytucje finansowe (2018 r.). Obawy inwestorów indywidualnych są uzasadnione, bowiem, jak potwierdziły badania, w przypadku potencjalnego krachu na rynku kapitałowym i związanej z tym niewypłacalności instytucji prowadzących działalność maklerską, ich aktywa zostaną utracone. Wyniki badań pokazały bowiem dużą dysproporcję (215 830\%), pomiędzy środkami zgromadzonymi w Systemie Rekompensat, a wartością aktywów zabezpieczanych przez ten System. Mimo, że w przypadku niewypłacalności instytucji pośredniczących w obrotach na rynku kapitałowym System narzuca ograniczenia w uzyskaniu rekompensaty, to w przypadku masowego bankructwa instytucji inwestycyjnych System będzie niewydolny.

Obawy inwestorów indywidualnych dotyczące ich bezpieczeństwa może budzić również niewielka wykrywalność przestępstw na rynku kapitałowym. Przeprowadzona analiza pokazała bowiem, że w ciągu sześciu lat wykryto tylko 199 przestępstw, które mają wpływ na inwestorów indywidualnych. Przestępstwa te w głównej mierze (83) dotyczyły złamania przepisów prawa wynikającego z ustawy o obrocie instrumentami finansowymi oraz ustawy o funduszach inwestycyjnych. Należy jednak domniemywać, iż nadużyć względem inwestorów indywidualnych jest znacznie więcej, czego dowodem jest działalność SII w zakresie oferowania usług zwiększających zakres ich ochrony.

Oprócz niedostatecznego zaplecza finansowego Systemu Rekompensat i niskiej wykrywalności przestępstw przeciw interesom inwestorów indywidualnych, 
analiza bezpieczeństwa konsumentów usług finansowych w Polsce ujawniła również brak spójności instytucjonalnej w tym zakresie. Rozproszenie instytucjonalne pomiędzy Rzecznika Finansowego, KDPW oraz ewentualne kancelarie prawne stanowi bowiem istotną barierę $\mathrm{W}$ zapewnieniu bezpieczeństwa usług finansowych. Wymienione instytucje zwykle oferują pomoc w przypadku naruszenia interesów inwestorów indywidualnych, a ich działalność prewencyjna jest znikoma. Lukę tę wypełnia Stowarzyszenie Inwestorów Indywidualnych, które w swojej ofercie zawarło cały wachlarz usług wpływających na poprawę bezpieczeństwa inwestorów indywidualnych.

Na podstawie powyższych konstatacji wysuwa się wniosek, że na rynku kapitałowym w Polsce występują dwa rodzaje ochrony konsumentów - ochrona bezpośrednia oraz ochrona pośrednia. Bezpośrednią ochronę konsumenta oferuje KDPW (System Rekompensat) oraz Stowarzyszenie Inwestorów Indywidualnych, w zakresie bezpośrednich interwencji w sytuacji naruszenia interesów inwestorów indywidualnych (np. pomoc prawna, reprezentacja inwestorów w postępowaniach karnych i sądowych, itp.). Ochrona pośrednia polega na podejmowaniu działań mających na celu zwiększenie poziomu bezpieczeństwa inwestorów indywidualnych, będącego konsekwencją podejmowania świadomych decyzji inwestycyjnych. Do działań tych należy zaliczyć przede wszystkim działalność edukacyjną, konsultacje analityczne, narzędzia analityczne czy popularyzację literatury przedmiotu. Jak pokazuje przykład SII, zakres ochrony konsumentów oferowany przez instytucje odpowiedzialne za prawidłowe funkcjonowanie rynku kapitałowego, powinien być spójny i zintegrowany. Zmniejszanie deficytów informacyjnych oraz deficytów edukacyjnych, podobnie jak wyrównanie strat wynikających z utraty wartości posiadanych zasobów w wyniku niewypłacalności biur maklerskich, w równym stopniu wpisuje się w procedurę zwiększania bezpieczeństwa i chroni konsumentów przed wymiernymi stratami na skutek działalności inwestycyjnej na rynku kapitałowym.

\section{BIBLIOGRAFIA}

Cichorska J. (red.), 2015, Zarzadzanie portfelem inwestycyjnym. Inwestor indywidualny na rynku finansowym, Wydawnictwo Uniwersytetu Ekonomicznego w Katowicach, Katowice.

DKN przy Rzeczniku Finansowym, 2019, Nieprawidłowości na rynku finansowym a ochrona konsumenta, Rzecznik Finansowy,Warszawa, https://rf.gov.pl/pdf/DKN_Raport_nieprawidlowosci_wrzesien2019.pdf [dostęp 15.09.2020].

Dyrektywa PE i Rady (UE) 2002/65/WE z dnia 23.09.2002 r. dotycząca sprzedaży konsumentom usług finansowych na odległość oraz zmieniająca dyrektywę Rady 90/619/EWG oraz dyrektywy 97/7/WE i 98/27/WE.

Dyrektywa PE i Rady 2005/29/WE z dnia 11.05.2005 r. dotycząca nieuczciwych praktyk handlowych stosowanych przez przedsiębiorstwa wobec konsumentów na rynku wewnętrznym oraz zmieniająca dyrektywę 84/450/EWG, dyrektywy 97/7/WE, 98/27/WE i 2002/65/WE Parlamentu Europejskiego i Rady i rozporządzenie 2006/2004. 
Dyrektywa PE i Rady 2011/83/UE z dnia 25.10.2011 r. w sprawie praw konsumentów, zmieniająca dyrektywę Rady 93/13/EWG i dyrektywę 1999/44/WE Parlamentu Europejskiego i Rady oraz uchylająca dyrektywę Rady 85/577/EWG i dyrektywę 97/7/WE Parlamentu Europejskiego i Rady Tekst mający znaczenie dla EOG.

Dyrektywa PE i Rady 2013/11/UE z dnia 21.05.2013 r. w sprawie alternatywnych metod rozstrzygania sporów konsumenckich oraz zmiany rozporządzenia (WE) nr 2006/2004 i dyrektywy 2009/22/WE (dyrektywa w sprawie ADR w sporach konsumenckich).

Dyrektywa PE i Rady 97/9/WE z dnia 3.03.1997 w sprawie systemów rekompensat dla inwestorów.

Frączek B., Mitręga-Niestrój K., 2015, Regulacyjno-instytucjonalne ramy ochrony konsumentów na rynku ustug finansowych - wybrane doświadczenia międzynarodowe, ,Zeszyty Naukowe Uniwersytet Ekonomiczny w Krakowie", nr 2(938), doi: 10.15678/ZNUEK.2015.0938.0201.

Gnela B., 2007, Ochrona konsumenta ustug finansowych. Wybrane zagadnienia, Wolters Kluwer, Warszawa.

GPW, 2017, Zagregowane wyniki badania dot. udziału inwestorów w obrotach instrumentami finansowymi, www.gpw.pl [dostęp 15.09.2020].

GPW, 2020, Udziat inwestorów w obrotach giełdowych, www.gpw.pl [dostęp 15.09.2020].

Iwanicz-Drozdowska M., Nowak A., Kitala R., 2009, Produkty finansowe i edukacja finansowa $w$ Polsce na tle wybranych krajów wysokorozwiniętych. Raport z badań, Wydawnictwo SGH, Warszawa.

Janik B., 2007, System rekompensat dla inwestorów giełdowych w Polsce na tle rozwiąań zagranicznych, Wydawnictwo Wyższej Szkoły Bankowej, Poznań-Gdańsk.

KDPW, 2018, Raport Roczny KDPW za rok 2018, https://www.kdpw.pl/pl/KDPW/publikacje/Documents/Raporty/raport2018.pdf [dostęp 15.09.2020].

KDPW, 2020, Podstawy prawne oraz zasady funkcjonowania Systemu Rekompensat w Polsce, https://www.kdpw.pl/pl/KDPW/publikacje/Documents/publikacje/SystemRekompensat.pdf [dostęp 15.09.2020].

Llewellyn D., 1999, The Economic Rationale for Financial Regulation, „Occasional Paper Series. The Financial Services Authority", no. 1.

NBP, 2014, Rozwój systemu finansowego w Polsce w 2013 r., Warszawa.

NBP, 2015, Rozwój systemu finansowego w Polsce w 2014 r., Warszawa.

NBP, 2016, Rozwój systemu finansowego w Polsce w 2015 r., Warszawa.

NBP, 2017, Rozwój systemu finansowego w Polsce w 2016 r., Warszawa.

NBP, 2018, Rozwój systemu finansowego w Polsce w 2017 r., Warszawa.

NBP, 2019, Rozwój systemu finansowego w Polsce w 2018 r., Warszawa

Rutkowska-Tomaszewska E., 2020a, Current trends in consumer protection regulations in the financial services market in Poland, [w:] S. Smyczek (ed.), Consumer Rights Protection. Threats and opportunities for enhancing consumer awareness, Publishing House of the Univesity of Economics in Katowice, Katowice.

Rutkowska-Tomaszewska E., 2020b, Prawo ochrony konsumenta ustug finansowych w świetle zatożenia racjonalnego ustawodawcy - kilka wybranych uwag, „Acta Universitatis Wratislaviensis", nr 3978, t. 120, doi: https://doi.org/10.19195/0137-1134.120.85.

Rzecznik Finansowy, 2017, Inwestycje w obligacje nie zawsze bezpieczne, https://rf.gov.pl/wp-content/uploads/2020/05/obligacje_korporacyjne_analiza_RF_2017.pdf [dostęp 15.09.2020].

Rzecznik Finansowy, 2018, Problemy klientów na ,,rynku forex”, https://rf.gov.pl/wp-content/uploads/2020/05/Forex_raport_RF_2018.pdf [dostęp 15.09.2020].

SII, 2015, Statut Stowarzyszenia Inwestorów Indywidualnych, http://www.sii.org.pl/static/img/000010/Statut_SII_20110122.pdf [dostęp 15.09.2020].

SII, 2019, Ogólnopolskie Bádanie Inwestorów - OBI 2019, SII, Wrocław [dostęp 15.09.2020].

SII, 2020a, Dziat Ochrony Praw, https://www.sii.org.pl/5/ochrona-praw.html\#ak5

[dostęp 15.09.2020]. 
SII, 2020b, O Stowarzyszeniu, http://www.sii.org.pl/3/stowarzyszenie.html\#ak3 [dostęp 15.09.2020].

Sójka T., 2016, Cywilnoprawna ochrona inwestorów korzystających z ustug maklerskich na rynku kapitałowym,Wolters Kluwer, Warszawa.

Szczepańska K., 2011, Pojęcie konsumenta w ,dyrektywach konsumenckich” Unii Europejskiej i orzecznictwie Trybunału Sprawiedliwości Unii Europejskiej - wybrane aspekty prawne, „Zeszyt Studencki Kół Naukowych Wydziału Prawa i Administracji UAM", nr 1, https://repozytorium.amu.edu.pl/bitstream/10593/13771/1/17_SZCZEPA\%c5\%83SKA.pdf [dostęp 15.09.2020].

Ustawa z dnia 23 kwietnia 1964 r. Kodeks Cywilny, Dz.U. 1964, nr 16, poz. 93.

Ustawa z dnia 27 maja 2004 r. o funduszach inwestycyjnych i zarzadzaniu alternatywnymi funduszami inwestycyjnymi, Dz.U. 2004, nr 146, poz. 1546

Ustawa z dnia 15 stycznia 2015 r. o o obligacjach, Dz.U. 2015, poz. 238.

Ustawa z dnia 29 maja 2005 r. o obrocie instrumentami finansowymi, Dz.U. 2005, nr 183, poz. 1538.

\title{
CONSUMER PROTECTION ON THE CAPITAL MARKET IN POLAND
}

\begin{abstract}
The proper functioning of the capital market is determined by maintaining the required level of security of its participants. Due to numerous threats, the capital market is particularly demanding for consumers who trade financial instruments at their own risk (individual investors). The main threats include, first of all, information deficits, volatile market conditions, as well as unfair market practices and bankruptcy of brokerage houses in which they keep financial instruments or cash.

The aim of the study is to indicate the scope of protection of consumers of financial services on the capital market. The study hypothesizes that the protection of consumers on the capital market is insufficient and requires the introduction of comprehensive solutions for a consistent protection system.

Two research methods are used in the article. The first method is the analysis of documents and legal acts. Its purpose is to present the scope of granting protection to consumers of brokerage services. The second research method is the empirical analysis of dynamics, the purpose of which is to identify trends and dynamics of changes in the activity of consumers of brokerage services.
\end{abstract}

Keywords: consumer protection, individual investors, Compensation System, brokerage services, capital market. 